Research Paper

\title{
Development of a new analog of SGK1 inhibitor and its evaluation as a therapeutic molecule of colorectal
}

\section{cancer}

\author{
Xuchun Liang1,\#, Chunling Lan²,\#, Jinzhe Zhou3,\#, Wencheng Fu¹, Xuesha Long1, Yu An², Guanming Jiao1, \\ Kejin Wang ${ }^{1}$, Yongqin $\mathrm{Li}^{1}$, Jiahong $\mathrm{Xu}^{4}$, Qi Huang ${ }^{3}$, Bin $\mathrm{Xu}^{2,}$, , Junjie Xiao ${ }^{1, \bigotimes}$ \\ 1. Regeneration and Ageing Lab, School of Life Science, Shanghai University, Shanghai 200444, China \\ 2. Department of Chemistry, Qianweichang College, Innovative Drug Research Center, Shanghai University, Shanghai 200444, China \\ 3. Department of General Surgery, Tongji Hospital, Tongji University School of Medicine, Shanghai 200065, China \\ 4. Department of Cardiology, Tongji Hospital, Tongji University School of Medicine, Shanghai 200065, China \\ \#These authors contributed equally to this work. \\ $\square$ Corresponding authors: Dr. Junjie Xiao Regeneration and Ageing Lab, School of Life Science, Shanghai University, 333 Nan Chen Road, Shanghai 200444, \\ China; Tel: 0086-21-66138131; Fax: 0086-21-66138131; E-mail: junjiexiao@shu.edu.cn. And Dr. Bin Xu Department of Chemistry, Innovative Drug Research \\ Center, 99 Shang Da Road, Shanghai 200444, China; Tel: 0086-21-66132830; Fax: 0086-21-66132830; E-mail: xubin@shu.edu.cn \\ (1) Ivyspring International Publisher. This is an open access article distributed under the terms of the Creative Commons Attribution (CC BY-NC) license \\ (https:// creativecommons.org/licenses/by-nc/4.0/). See http://ivyspring.com/terms for full terms and conditions.
}

Received: 2017.02.08; Accepted: 2017.05.02; Published: 2017.07.20

\begin{abstract}
Colorectal cancer (CRC) is one of the most leading causes of cancer-related death worldwide. The serum and glucocorticoid inducible kinase SGK1 is highly expressed and involved in several tumors. GSK650394, a SGK1 inhibitor, has been proved to be effective in impeding tumor growth in vitro. In this study, we developed a novel analog of GSK650394, and evaluated its effects on CRC cells and tumor growth both in vitro and in vivo. HCT116 cells were treated with a concentration gradient of new developed compounds and cholecystokinin octapeptide (CCK-8) assay was used to calculate the IC50 value of every analog. Cell proliferation analysis was estimated from EdU staining and flow cytometry in vitro, and immunohistochemistry of Ki67 and PCNA in vivo. Cell migration analysis was examined using the transwell assay. In vivo tumor growth was determined in athymic nude mice by injecting the HCTI16 cells in the subcutaneous tissue, followed by the injection of QGY-5-114-A. We found that new developed GSK650394 analog QGY-5-114-A has lower IC50 value, and treatment with QGY-5-114-A significantly inhibited CRC cell proliferation and migration in vitro. Besides that, colonic tumor growth was also dramatically restricted by QGY-5-114-A in vivo. In conclusion, pharmacological treatment with QGY-5-114-A impedes CRC tumor cell proliferation, migration and tumor growth.
\end{abstract}

Key words: Colorectal cancer; Serum and glucocorticoid inducible kinase 1; Inhibitor; Cell proliferation; Cell migration; Colonic tumor growth

\section{Introduction}

Colorectal cancer (CRC) is the most frequently diagnosed cancer, and remains the leading cause of cancer-related death worldwide [1]. The cause of CRC is very complex and diverse, including multiple factors such as diet, genetic predisposition, lifestyle, environmental factors and the presence of longstanding inflammatory bowel diseases [2-4]. Multiple systems and pathways are involved in colorectal carcinogenesis and contribute to the tumor initiation and development. Abnormal DNA methylation, chromosomal instability pathway, inflammation, microRNA, DNA Mismatch Repair (MMR) system and consequential microsatellite instability (MSI) have been reported to be responsible for CRC [5-9]. Various therapeutic agents targeting the abovementioned pathways have resulted in a significant 
reduction of mortality in early stage CRC. However, the morbidity and mortality remain high in patients with advanced stage disease [10]. Thus, the optimization of clinical treatment and the investigation of novel molecular-targeted therapeutics for CRC are critically needed.

Serum-and glucocorticoid-regulated kinase 1 (SGK1) belongs to the AGC family of serine/ threonine protein kinases. SGK1 is up-regulated by insulin and growth factors through the phosphatidylinositide-3-kinase (PI3K), 3-phosphoinositide dependent kinase (PDK1) and PDK2 [11]. SGK1 promotes tumor growth by enhancing tumor cell survival, motility, invasiveness, adhesiveness and epithelial to mesenchymal transition [12-14]. Following deficiency of APC (adenoma polyposis coli), SGK1 knockout mice developed less intestinal tumors than their wild-type littermates [15]. In addition, SGK1 inhibitors (GSK650394, LY294002 and EMD638683) proved to be effective in vitro against prostate cancer cells [16], breast cancer [13] and the colorectal cancer [17]. Thus, we hypothesized that SGK1 would be an attractive target for developing novel anti-CRC therapies.

In this study, we designed and synthesized 39 new analogs of SGK1 inhibitor GSK650394. And one of these compounds named as QGY-5-114-A was more effective than GSK650394 in vitro and in vivo against colonic tumor cells. Therefore, the present study develops a new competitive inhibitor of SGK1, which is likely to have therapeutic utility in CRC.

\section{Methods}

Preparation of Phenyl(1-phenyl-1H-pyrrolo[2,3b]pyridin-3-yl)methanone (General Procedure) [17]: 1-phenyl-1H-pyrrolo[2,3- $b$ ]pyridine $(0.39 \mathrm{~g}, 2.0 \mathrm{~mm}$ ol) was added to a stirred suspension of $\mathrm{AlCl}_{3}(1.4 \mathrm{~g}$, $10 \mathrm{mmol})$ in $\mathrm{CH}_{2} \mathrm{Cl}_{2}(48 \mathrm{~mL})$. After the mixture was stirred at room temperature for $1 \mathrm{~h}$, benzoyl chloride $(1.4 \mathrm{~g}, 10 \mathrm{mmol})$ was added dropwise and the resulting mixture stirred for $21 \mathrm{~h}$. $\mathrm{MeOH}(10 \mathrm{~mL})$ was added cautiously to quench the reaction, the solvents were removed under vacuum, and the residual solid was purified by flash chromatography on silica gel (petroleum ether/EtOAc $=10: 1)$ to afford $3 f(0.45 \mathrm{~g}$, $75 \%)$ as a white solid.

Preparation of (1-(2-Chlorophenyl)-1H-pyrrolo [2,3-b]pyridin-3-yl)(phenyl)- methanone (QGY-5114-A) (General Procedure) [17]: To a $15 \mathrm{~mL}$ sealed tube was added phenyl(1-phenyl- $1 H$ - pyrrolo[2,3b]pyridin-3-yl)methanone (89.5 $\mathrm{mg}, 0.3 \mathrm{mmol})$, $\left[\mathrm{RhCp}^{*} \mathrm{Cl}_{2}\right]_{2}(3.7 \mathrm{mg}, 0.006 \mathrm{mmol}), \mathrm{Cu}(\mathrm{TFA})_{2}(174 \mathrm{mg}$, $0.6 \mathrm{mmol}), \mathrm{Li}_{2} \mathrm{CO}_{3}(22 \mathrm{mg}, 0.3 \mathrm{mmol}), t-\mathrm{BuNC}$ (50 mg, $0.6 \mathrm{mmol})$ and DCE $(1.5 \mathrm{~mL})$. The reaction mixture was stirred at $130{ }^{\circ} \mathrm{C}$ under air atmosphere. After reacted for $46 \mathrm{~h}$, the reaction was diluted by EtOAc $(10$ $\mathrm{mL}$ ) and quenched with aqueous ammonia solution (3 $\mathrm{M}, 10 \mathrm{~mL}$ ). The aqueous layer was extracted with EtOAc $(3 \times 10 \mathrm{~mL})$ and the combined extract was dried over $\mathrm{Na}_{2} \mathrm{SO}_{4}$, filtered, and concentrated in vacuo. The given residue was purified by column chromatography on silica gel (petroleum ether $/$ EtOAc $=20: 1$ ) to give the clorinated product QGY-5-114-A (70.9 mg, $71 \%)$ as a white solid.

\section{Cell culture}

Colorectal cancer cell lines HCT116 and HT29 were purchased from KeyGEN BioTECH. CO., LTD (Nanjing, China). HCT116 cells were cultured in Dulbecco's modified Eagle's medium (DMEM, Corning) supplemented with 10\% fetal bovine serum (FBS, CellMax) and 1\% PS (penicillin-streptomycin, Gibco), and HT29 cells were cultured in RPMI 1640 medium (KeyGEN) supplemented with 10\% FBS (Biological Industries) and 1\% PS, and maintained in a humidified atmosphere containing $5 \% \mathrm{CO}_{2}$ at $37^{\circ} \mathrm{C}$.

\section{Cell viability assay}

Cell viability was detected using the cholecystokinin octapeptide (CCK-8) assay (Bioworld). After 6-8 h starvation, HCT116 cells were plated in 96 well plate at $2 \times 10^{5}$ cells $/ \mathrm{mL}$ per well, and grown for $24 \mathrm{~h}$. Then, cells were treated with various concentrations of compounds $(0,25,50,75,100$ and $200 \mu \mathrm{M})$ for $24 \mathrm{~h}, 1$ hour before the end of the experiment, CCK-8 was added and incubated in $37{ }^{\circ} \mathrm{C}$ blocking the light following the manufacturer's instructions. Then the cell proliferation inhibition was calculated by measuring the optical density values (OD) at $450 \mathrm{~nm}$ using microplate reader (Bio-Rad), the half maximal inhibitory concentration (IC50) value of every compound on HCT116 cells was calculated using SPSS software through probit model by logit-transformed.

\section{Flow cytometry}

HCT116 and HT29 cells were plated in 12 well culture plastic dish at $2 \times 10^{5}$ cells per well. Briefly, cells were treated with vehicle DMSO or $50 \mu \mathrm{M}$ compound for $24 \mathrm{~h}$. After cold ethanol fixation overnight, cells were resuspended in $100 \mu \mathrm{l}$ PBS. Subsequently, these samples were assessed using propidium iodide (PI, Sigma) staining followed by flow cytometry (Beckman).

\section{EdU proliferation assay}

Detection of compounds effect on HCT116 and HT29 cell proliferation was performed according to the manual of Cell-Light ${ }^{\mathrm{TM}}$ EdU Apollo ${ }^{\circledR} 488$ Cell Tracking Kit (Ribobio). Two hours before the end of cell treatment by compound, $50 \mu \mathrm{M}$ EdU labeling 
medium was added to the cell culture to finish co-incubation. Afterwards, cells were washed with PBS and fixed with $4 \%$ paraformaldehyde overnight and neutralized with glycine for $5 \mathrm{~min}$. After washed with PBS and $0.5 \%$ TritonX-100 for $10 \mathrm{~min}$, anti-EdU working solution was added to stain at room temperature for $30 \mathrm{~min}$. Subsequently, the DNA contents were stained with $5 \mu \mathrm{g} / \mathrm{ml}$ Hoechst 33342 for $30 \mathrm{~min}$, and then observed under a fluorescent microscope (Leica Microsystems). The quantity of cell nuclear was calculated with Cell Profiler software.

\section{Migration}

The migration ability of HCT116 cells was examined in $6.5 \mathrm{~mm}$ transwell chambers with $8 \mu \mathrm{m}$ pores (Costar). Briefly, $600 \mu \mathrm{l}$ DMEM supplemented with $10 \%$ FBS was added to the bottom chamber. 200 $\mu \mathrm{l}$ resuspended cells $\left(2 \times 10^{6} / \mathrm{ml}\right)$ treated with compound in serum-free DMEM were added to the top chamber. After migration for $48 \mathrm{~h}$, cleaned cells upper surface of the membrane with a cotton swab and washed with PBS. Then the chamber was stained with crystal violet (Bioworld) for $5 \mathrm{~min}$. The quantity of cells on the bottom of the membrane was performed under a microscope (Leica Microsystems).

\section{Mice and treatment}

Athymic nude mice aged 6 weeks were purchased from the Cavens lab (Changzhou, China). Under SPF conditions, the mice were bred in $12 \mathrm{~h}$ light/12 $\mathrm{h}$ dark cycle in an airy room at constant temperature about $21-23{ }^{\circ} \mathrm{C}$. All animal experiments were conducted in accordance with institutional guidelines. Transplanted tumors were generated through implanting subcutaneously in 8-week old mice. HCT116 cells were suspended in 10\% Matrigel and injected in the subcutaneous tissue of nude mice at a density of $3 \times 10^{6}$ cells $/ 200 \mu \mathrm{L}$ per mouse. After two weeks, compound ( $50 \mathrm{mM}, 1: 5$ dilution, $40 \mu \mathrm{l})$ was injected around the subcutaneous every other day. Transplanted tumors were dissected after xenograft implantation 8 days, and then measured, fixed in $4 \%$ PFA and frozen in liquid nitrogen until use.

\section{Immunohistochemistry on tissue section}

Tissues from the xenograft tumor were embedded in paraffin and sliced to $5-\mu \mathrm{m}$ thickness. Tissue sections were maintained in a $65^{\circ} \mathrm{C}$ incubator 2 $\mathrm{h}$ for drying. After dewaxing and dehydration, antigens were unmasked by pressure cooking for 10 min in citrate buffer according to antibody specification. Then sections were immersed in $0.3 \%$ hydrogen peroxide for $10 \mathrm{~min}$ to destruct the endogenous peroxidase activity. The next steps were performed avoiding exposing to light. 5\% BSA used to block non-specific binding for $5 \mathrm{~min}$, subsequently covered each slice with $50 \mu \mathrm{L}$ primary antibodies against Ki67 (Abcam, 1:300, v/v, dilution), PCNA (Proteintech, 1:300, v/v, dilution), incubation overnight at $4{ }^{\circ} \mathrm{C}$. Then covered with appropriate secondary antibodies for $1 \mathrm{~h}$ at room temperature and added each slice with fresh prepared 3,3-diaminobenzidine tetrahydrochloride (DAB) solution and hematoxylin counterstain. After staining, sections were dehydrated through increasing concentrations of ethanol and xylene. A total of 15 fields were randomly selected for each section in the viable region of the tumor under the microscope after mounted coverslip with neutral resin containing xylene.

\section{Statistical analysis}

All statistics of experiments were analyzed by GraphPad Prism 5.0 or SPSS20.0 software. All data were shown as mean \pm SE. A Student's $t$ test was performed to determine difference between the control and treated group. For all of the tests, $P<0.05$ was considered statistically significant.

\section{Results}

\section{IC50 and kinetic analysis of QGY-5-114-A}

We first designed and synthesized new 39 analogs of SGK1 inhibitor GSK650394 (Fig. 1). We then preliminarily examined their inhibitory activities with CCK-8 assay. The results showed that those analogs, numbered as MH-1-11-A, MH1-11-B, QGY-590, QGY-OMe, QGY-5-163, QGY-5-114-A and QGY$5-121$, could inhibit the cell viability in colonic tumor cell line HCT116 (Fig. 2A). To compare the inhibitory potency of these 7 analogs, we calculated their IC50 values by determining the concentration needed to inhibit half of the maximum cell viability of these compounds. Using CCK-8 assay, we showed that GSK650394 inhibited HCT116 cell viability with an IC50 value of $135.5 \mu \mathrm{M}$. And only compound QGY-5-114-A showed a significantly lower IC50 value of $122.9 \mu \mathrm{M}$, indicating the better inhibitory potency than commercial inhibitor GSK650394 (Fig. 2B and Table 1).

\section{QGY-5-114-A restrains colonic tumor cell proliferation}

Several studies have showed that SGK1 regulates survival, proliferation, migration and invasion of cancer cells. In this study, we first evaluated the proliferation of HCT116 cells treated with QGY-5-114-A. The results showed that QGY-5114-A inhibited HCT116 cell proliferation, revealed by a significant decrease in EdU staining (Fig. 3A). This conclusion was further confirmed by cell cycle analysis via flow cytometry (Fig. 3B). 


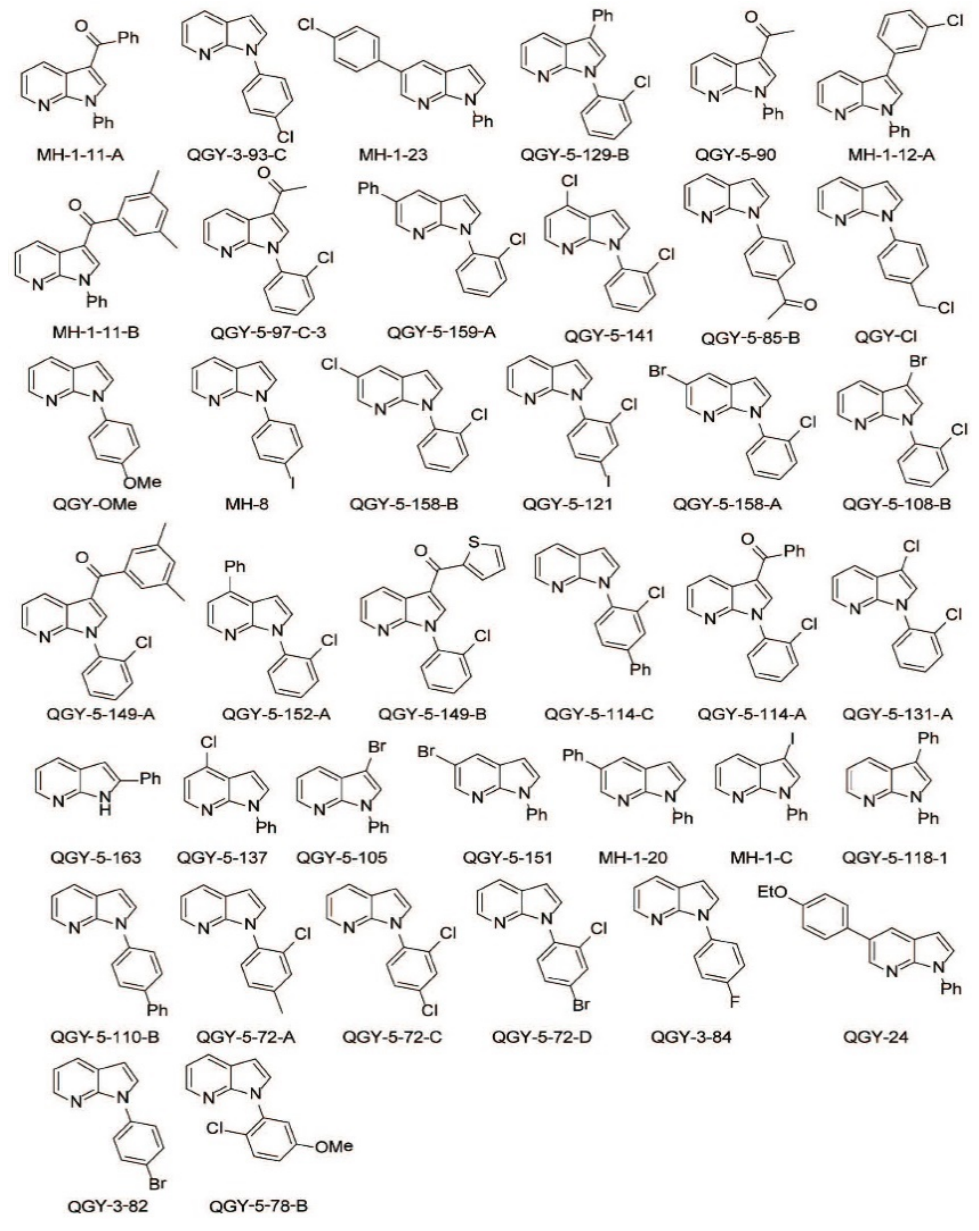

Fig. 1. Chemical structure of GSK650394 and 39 new developed analogs.

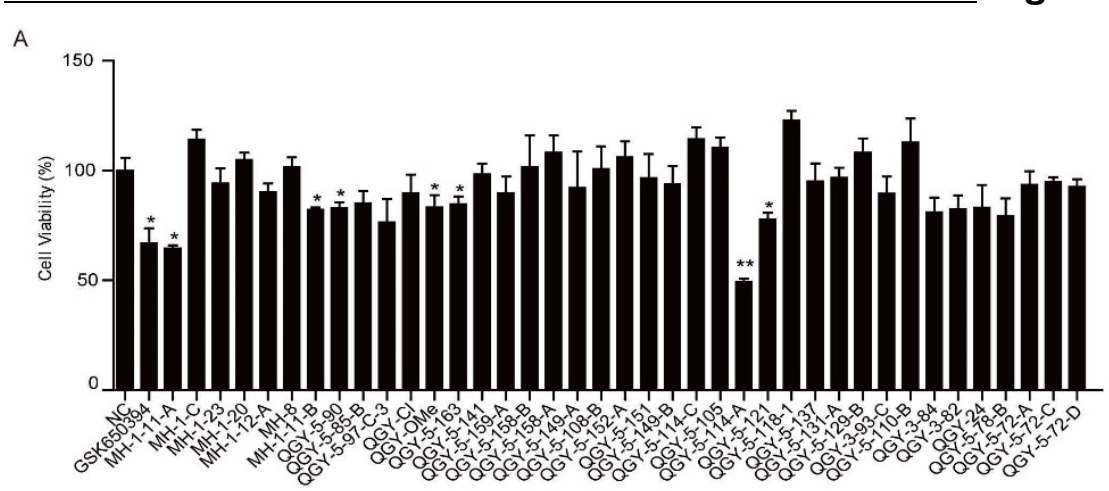

B

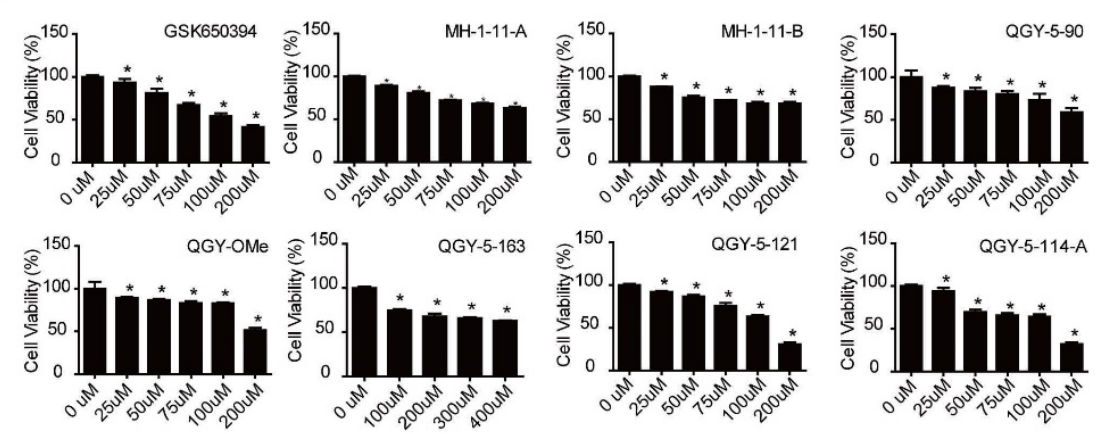

Fig. 2. Seven compounds of the 39 newly developed GSK650394 analogs suppress cell viability. (A) Cell viability analysis of HT1 16 cells treated with $50 \mu$ M GSK650394 and 39 new analogs, as determined by CCK-8 assay. (B) Cell viability analysis of HT1 16 cells treated with various concentrations of compounds.
The cell cycle distribution of HCT116 cells was affected by QGY-5-114-A, with a significant increase in G0/G1 population and a decrease in $S$ phase cells. In order to investigate whether QGY-5-114-A could affect other colonic tumor cells, we also performed EdU staining and cell cycle analysis in HT29 cells. The same results were obtained (Fig. 4A and Fig. 4B). Taken together, our results revealed that QGY-5-114 -A could suppress the proliferation of colonic tumor cells.

\section{QGY-5-114-A impedes colonic tumor cell migration in vitro}

CRC is one of the most lethal malignancies, with the high rates of metastasis. To explore the biological functions of QGY-5-114-A in CRC migration ability, we first performed transwell migration assay in HCT116 cells. Cells treated with QGY-5-114A displayed impaired migration (Fig. 5A), and the percentage of cells on the bottom of membrane was notably lower than control cells (Fig. 5B). These results indicated that QGY-5-114-A restrains CRC metastasis in vitro.

\section{QGY-5-114-A inhibits colonic tumor growth and cell proliferation in vivo}

We explored the therapeutic effect of QGY-5-114-A on CRC growth by administering it into nude mice. CRC implant tumors were induced by subcutaneous injection of HCT116 cells, followed by treatment with the compound QGY-5-114-A (Fig. 6A). The results showed that QGY-5-114-A prominently reduced xenograft tumor size and volume until the mice were dissected on day 8 (Fig. 6B and 6C). In addition, we detected the xenograft tumor tissues by immunohistochemical analysis for proliferation markers including Ki67 and PCNA (Fig. 6D). In xenograft tumors treated with QGY-5-114-A, PCNA- and Ki67-positive cell populations were dramatically reduced. Collectively, these results suggest that QGY-5-114-A is impactful to depress the proliferation of CRC cells and tumor growth during the CRC development. 


\section{Discussion}

The present study describes the development of a novel compound, QGY-5-114-A, that was a new analog of SGK1 inhibitor GSK650394. We also examined the effects of QGY-5-114-A on CRC tumor cell proliferation, migration and tumor growth. GSK650394, a commercial inhibitor of SGK1, has previously been shown to antagonize SGK1 activity and inhibit prostate cancer cell growth [16]. Our results showed that, compared with GSK650394, this novel compound QGY-5-114-A has lower molecular weight, simpler chemical structure and lower IC50 value (Fig. 1, 2 and Table 1), indicating that QGY-5-
114-A has a promising application prospect as SGK1 inhibitor.

Table 1. The IC50 value of SGK650394 and new developed chemical compounds

\begin{tabular}{ll}
\hline Number & IC50 \\
\hline GSK650394 & $135.5 \mu \mathrm{M}$ \\
MH-1-11-A & $346.4 \mu \mathrm{M}$ \\
MH-1-11-B & $473.0 \mu \mathrm{M}$ \\
QGY-5-90 & $340.8 \mu \mathrm{M}$ \\
QGY-OMe & $266.9 \mu \mathrm{M}$ \\
QGY-5-163 & $1528.7 \mu \mathrm{M}$ \\
QGY-5-114-A & $122.9 \mu \mathrm{M}$ \\
QGY-5-121 & $133.9 \mu \mathrm{M}$ \\
\hline
\end{tabular}

A

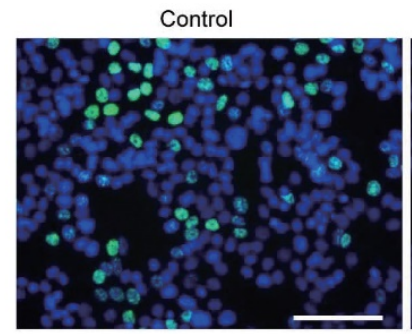

B

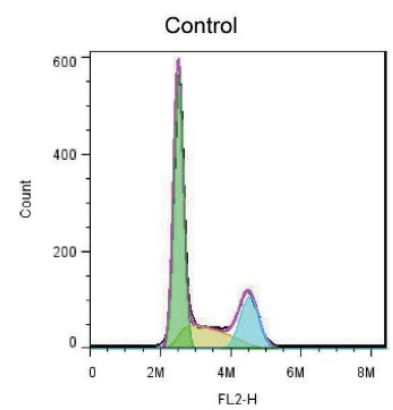

QGY-5-114-A

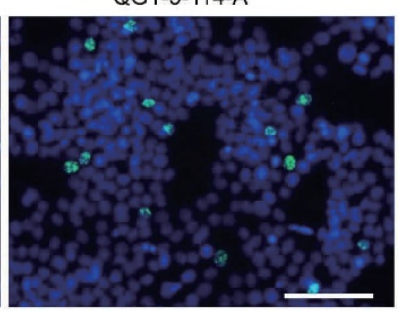

QGY-5-114-A

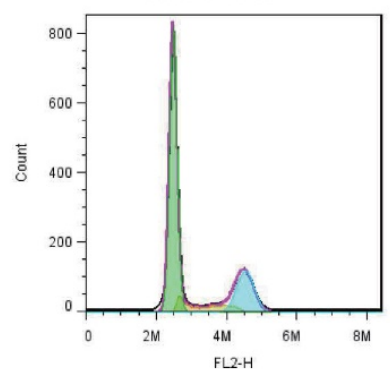

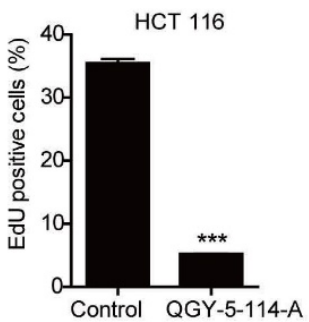

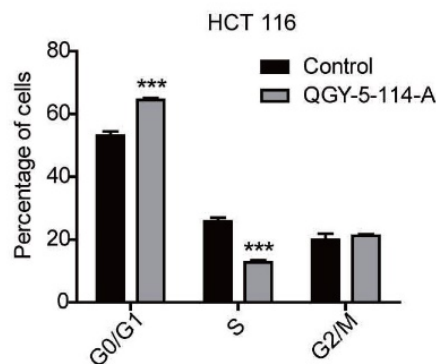

Fig. 3 QGY-5-114-A inhibits HCT116 cell proliferation. (A) EdU staining of HCT116 cells and EdU-positive cell proportion. Scale bar, $100 \mu \mathrm{m} ; \mathrm{n}=4$; ***, $\mathrm{P}<0.001$; (B) HCT116 cell cycle analysis by flow cytometry. ***, $\mathrm{P}<0.001$.

A
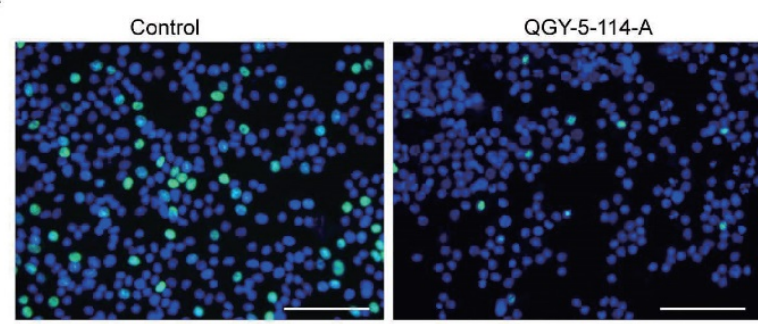

B

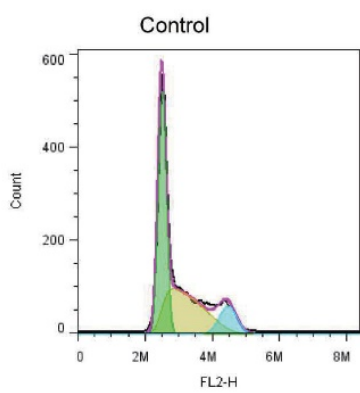

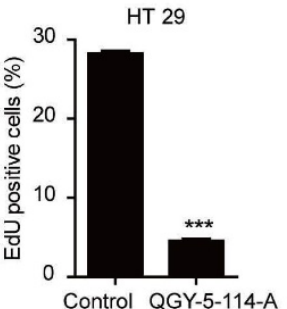
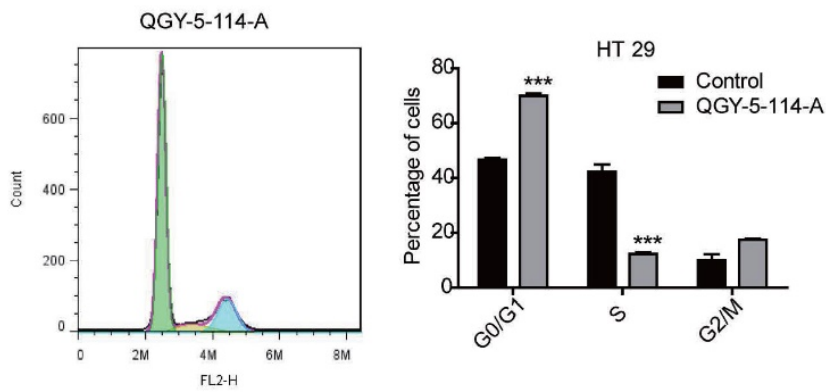

Fig. 4 QGY-5-1 14-A inhibits HT29 cell proliferation. (A) EdU staining of HT29 cells and EdU-positive cell proportion. Scale bar, $100 \mu$ m; $n=4$; ***, P<0.001; (B) Cell cycle analysis of $\mathrm{HT} 29$ cells by flow cytometry. $* * *, \mathrm{P}<0.001$. 

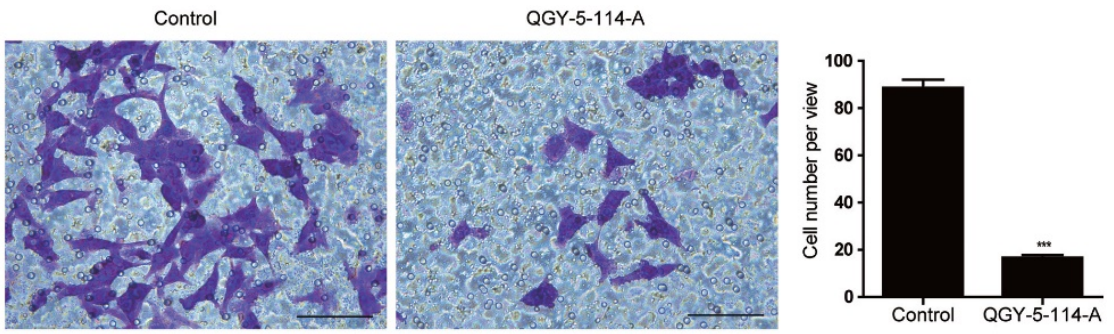

Fig. 5 QGY-5-1 14-A suppresses the migration of HCT 116 cells. Decrease in HCT1 16 cell numbers after migration for 48 hours by QGY-5-116, $n=4$; Scale bars, $100 \mu \mathrm{m} ; * * *, \mathrm{P}<0.001$.

A

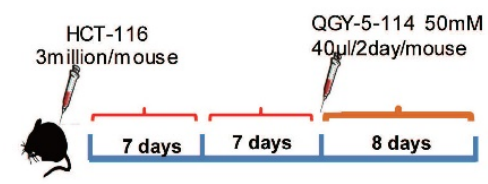

C

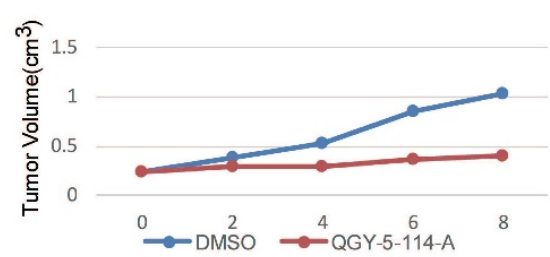

D
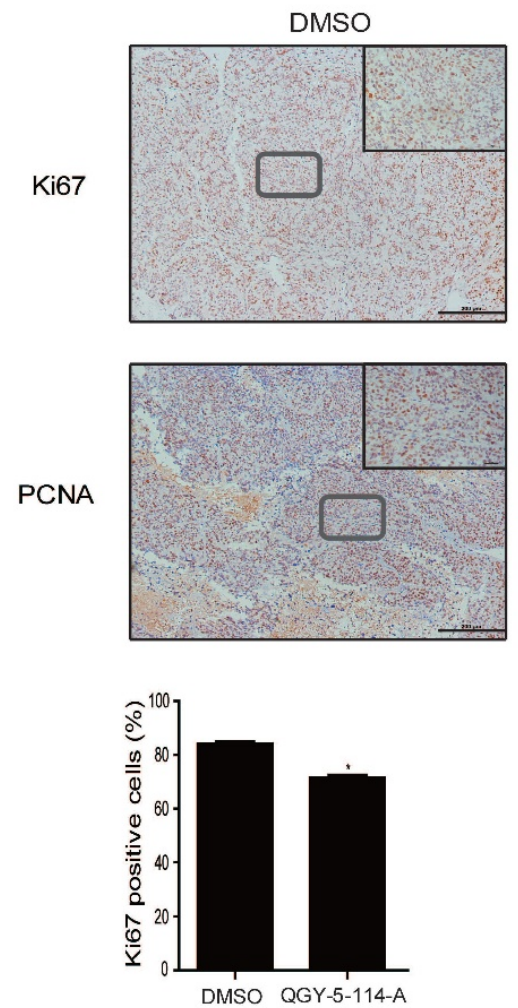
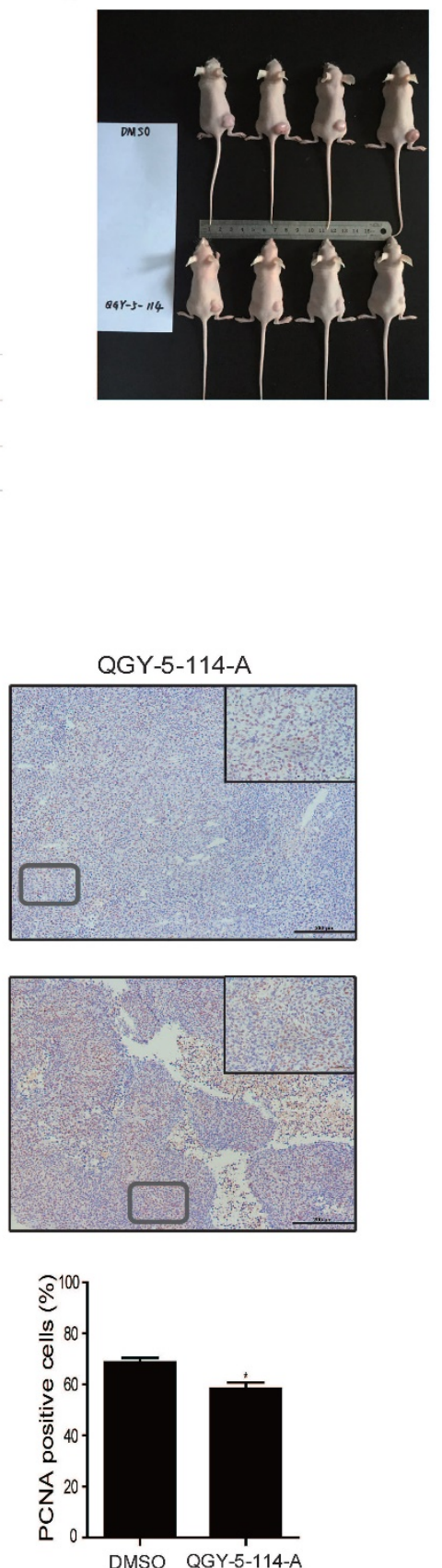

Fig. 6 QGY-5-114-A restrains tumor growth and cell proliferation in subcutaneous xenograft mice model. (A) The procedure of establishing the xenotransplant mice model. (B) Transplanted tumor size of control and mice injected with QGY-5-114-A. n=4; (C) Transplanted tumor volume. $n=4$; (D) Reduction in Ki67- and PCNA-positive cell populations in skin tissues treated with QGY-5-114-A. Scale bars, $200 \mu \mathrm{m}$; *, P<0.05;

Previous studies reported that GSK650394 inhibits the enzymatic activity of both SGK1 and other members of the SGK protein family [16], and another SGK1 commercial inhibitor EMD638683 also inhibits the other two SGK1 isoforms with similar potency [18]. Therefore, extensive studies are needed to determine the specificity and effectiveness of QGY5-114-A in inhibiting the enzymatic activity of SGK1.

The inhibition of colonic tumor growth by QGY-5-114-A is fully consistent with the previous reports that SGK1 mutation reduces spontaneous intestinal tumor number in APCdeficient mice [15] and SGK1 inhibition counteracts colonic tumor growth in vivo [17]. Several mechanisms, such as mTOR, FOXO3a, $\beta$-catenin, p53 and NF-kB, have been reported or predicted to be involved in SGK1dependent tumor cell proliferation and tumor growth [19-25]. However, the explicit molecular mechanism of SGK1 in regulating colorectal cancer is still not clear. Accordingly, QGY-5-114 -A will facilitate the identification of pathways regulated by SGK1 in CRC, which may develop more effective CRC treatments. Besides that, the identification and characterization of novel SGK1 antagonist by performing optimization on the basis of known compounds could be emulated by the identification of other small molecule inhibitors with ideal pharmacokinetic characteristics.

In conclusion, we developed 39 novel analogs of SGK1 inhibitor GSK650394 and one of them, QGY-5114-A, has lower molecular weight and IC50 value. Treatment with 
QGY-5-114-A significantly restrains colonic tumor cell proliferation, migration and tumor growth, indicating QGY-5-114-A will be a promising therapeutic inhibitor in the treatment of CRC and other malignancies.

\section{Abbreviations}

CRC, colorectal cancer; MMR, mismatch repair; SGK1, serum-and glucocorticoid-regulated kinase 1; PI3K, phosphatidylinositide-3-kinase; PDK1, 3-phosphoinositide dependent kinase; APC, adenoma polyposis coli.

\section{Acknowledgement}

This work was supported by the grants from National Natural Science Foundation of China (81470515 to JH Xu and 21672136 to B Xu), Shanghai Medical Guide Project from Shanghai Science and Technology Committee (134119a3000 to $\mathrm{JH} \mathrm{Xu}$ ) and the development fund for Shanghai talents (to JJ Xiao).

\section{Competing Interests}

The authors declare no competing financial interests.

\section{References}

1. Siegel RL, Miller KD, Jemal A. Cancer statistics, 2016. CA Cancer J Clin. 2016; 66: 7-30.

2. Burn J, Gerdes AM, Macrae F, Mecklin JP, Moeslein G, Olschwang S, et al. Long-term effect of aspirin on cancer risk in carriers of hereditary colorectal cancer: an analysis from the CAPP2 randomised controlled trial. Lancet. 2011; 378: 2081-7.

3. Cappellani A, Zanghi A, Di Vita M, Cavallaro A, Piccolo G, Veroux P, et al. Strong correlation between diet and development of colorectal cancer. Front Biosci (Landmark Ed). 2013; 18: 190-8.

4. Abu-Remaileh M, Bender S, Raddatz G, Ansari I, Cohen D, Gutekunst J, et al. Chronic inflammation induces a novel epigenetic program that is conserved in intestinal adenomas and in colorectal cancer. Cancer Res. 2015; 75: 2120-30.

5. Wheeler JM, Bodmer WF, Mortensen NJ. DNA mismatch repair genes and colorectal cancer. Gut. 2000; 47: 148-53.

6. Gyparaki MT, Basdra EK, Papavassiliou AG. DNA methylation biomarkers as diagnostic and prognostic tools in colorectal cancer. J Mol Med (Berl). 2013; 91: 1249-56.

7. Garcia-Anguita A, Kakourou A, Tsilidis KK. Biomarkers of Inflammation and Immune Function and Risk of Colorectal Cancer. Curr Colorectal Cancer Rep. 2015; 11: 250-8.

8. Amirkhah R, Schmitz U, Linnebacher M, Wolkenhauer O, Farazmand A. MicroRNA-mRNA interactions in colorectal cancer and their role in tumor progression. Genes Chromosomes Cancer. 2015; 54: 129-41.

9. Gupta S, Ashfaq R, Kapur P, Afonso BB, Nguyen TP, Ansari F, et al. Microsatellite instability among individuals of Hispanic origin with colorectal cancer. Cancer. 2010; 116: 4965-72.

10. Schlussel AT, Gagliano RA, Jr., Seto-Donlon S, Eggerding F, Donlon T, Berenberg J, et al. The evolution of colorectal cancer genetics-Part 1: from discovery to practice. J Gastrointest Oncol. 2014; 5: 326-35.

11. Kobayashi T, Cohen P. Activation of serum- and glucocorticoid-regulated protein kinase by agonists that activate phosphatidylinositide 3-kinase is mediated by 3-phosphoinositide-dependent protein kinase-1 (PDK1) and PDK2. Biochem J. 1999; 339 (Pt 2): 319-28.

12. Wu W, Chaudhuri S, Brickley DR, Pang D, Karrison T, Conzen SD. Microarray analysis reveals glucocorticoid-regulated survival genes that are associated with inhibition of apoptosis in breast epithelial cells. Cancer Res. 2004; 64: 1757-64.

13. Tangir J, Bonafe N, Gilmore-Hebert M, Henegariu O, Chambers SK. SGK1, a potential regulator of $\mathrm{c}-\mathrm{fms}$ related breast cancer aggressiveness. Clin Exp Metastasis. 2004; 21: 477-83.

14. Cheng J, Truong LD, Wu X, Kuhl D, Lang F, Du J. Serum- and glucocorticoid-regulated kinase 1 is upregulated following unilateral ureteral obstruction causing epithelial-mesenchymal transition. Kidney Int. 2010; 78: 668-78.
15. Wang $\mathrm{K}, \mathrm{Gu} \mathrm{S}$, Nasir $\mathrm{O}$, Foller $\mathrm{M}$, Ackermann $\mathrm{TF}$, Klingel $\mathrm{K}$, et al. SGK1-dependent intestinal tumor growth in APC-deficient mice. Cell Physiol Biochem. 2010; 25: 271-8.

16. Sherk AB, Frigo DE, Schnackenberg CG, Bray JD, Laping NJ, Trizna W, et al. Development of a small-molecule serum- and glucocorticoid-regulated kinase-1 antagonist and its evaluation as a prostate cancer therapeutic. Cancer Res. 2008; 68: 7475-83.

17. Towhid ST, Liu GL, Ackermann TF, Beier N, Scholz W, Fuchss T, et al. Inhibition of colonic tumor growth by the selective SGK inhibitor EMD638683. Cell Physiol Biochem. 2013; 32: 838-48.

18. Ackermann TF, Boini KM, Beier N, Scholz W, Fuchss T, Lang F. EMD638683, a novel SGK inhibitor with antihypertensive potency. Cell Physiol Biochem. 2011; 28: 137-46.

19. Feng Z, Liu L, Zhang C, Zheng T, Wang J, Lin M, et al. Chronic restraint stress attenuates p53 function and promotes tumorigenesis. Proc Natl Acad Sci U S A. 2012; 109: 7013-8.

20. Amato R, D'Antona L, Porciatti G, Agosti V, Menniti M, Rinaldo C, et al. Sgk1 activates MDM2-dependent p53 degradation and affects cell proliferation, survival, and differentiation. J Mol Med (Berl). 2009; 87: 1221-39.

21. You H, Jang Y, You-Ten AI, Okada H, Liepa J, Wakeham A, et al. p53-dependent inhibition of FKHRL1 in response to DNA damage through protein kinase SGK1. Proc Natl Acad Sci U S A. 2004; 101: 14057-62.

22. Mikosz CA, Brickley DR, Sharkey MS, Moran TW, Conzen SD. Glucocorticoid receptor-mediated protection from apoptosis is associated with induction of the serine/threonine survival kinase gene, sgk-1. J Biol Chem. 2001; 276: 16649-54.

23. Zhang L, Cui $R$, Cheng $X$, Du J. Antiapoptotic effect of serum and glucocorticoid-inducible protein kinase is mediated by novel mechanism activating I\{kappa\}B kinase. Cancer Res. 2005; 65: 457-64.

24. Avruch J, Hara K, Lin Y, Liu M, Long X, Ortiz-Vega S, et al. Insulin and amino-acid regulation of mTOR signaling and kinase activity through the Rheb GTPase. Oncogene. 2006; 25: 6361-72.

25. Xu Y, Chen SY, Ross KN, Balk SP. Androgens induce prostate cancer cell proliferation through mammalian target of rapamycin activation and post-transcriptional increases in cyclin D proteins. Cancer Res. 2006; 66: 7783-92. 